TIBOPTIH ${ }^{\circ}$

- незамінний донатор оксиду азоту
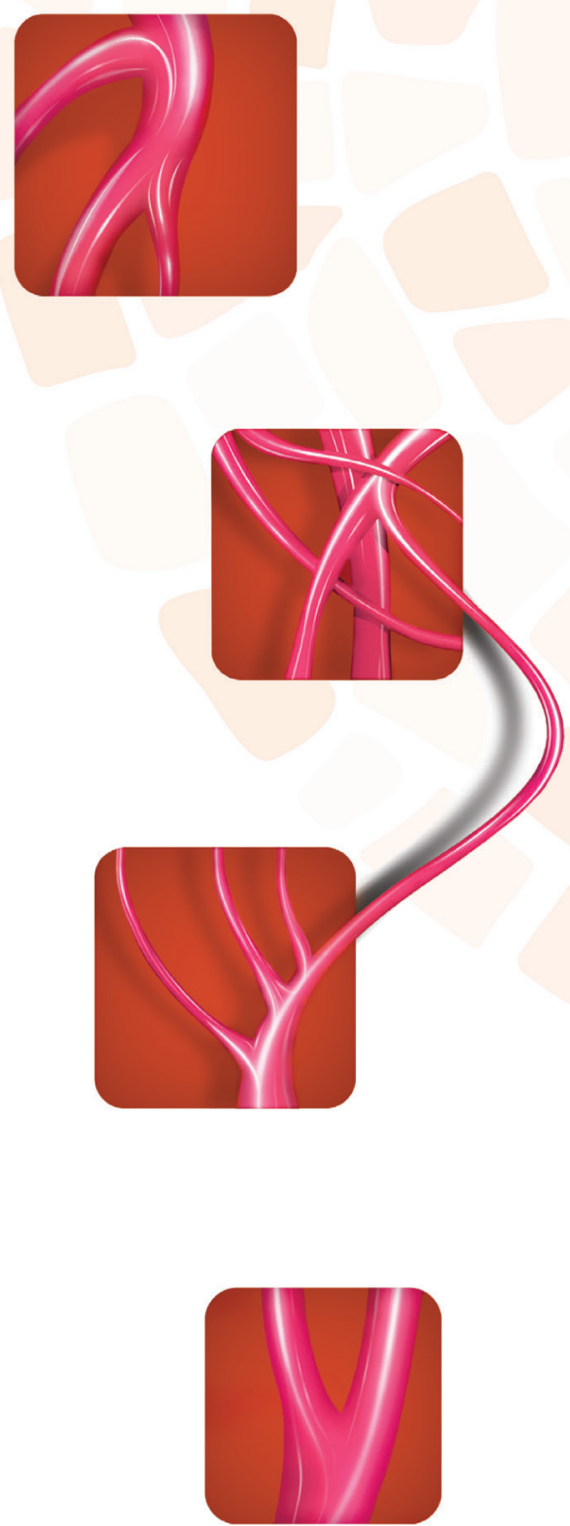

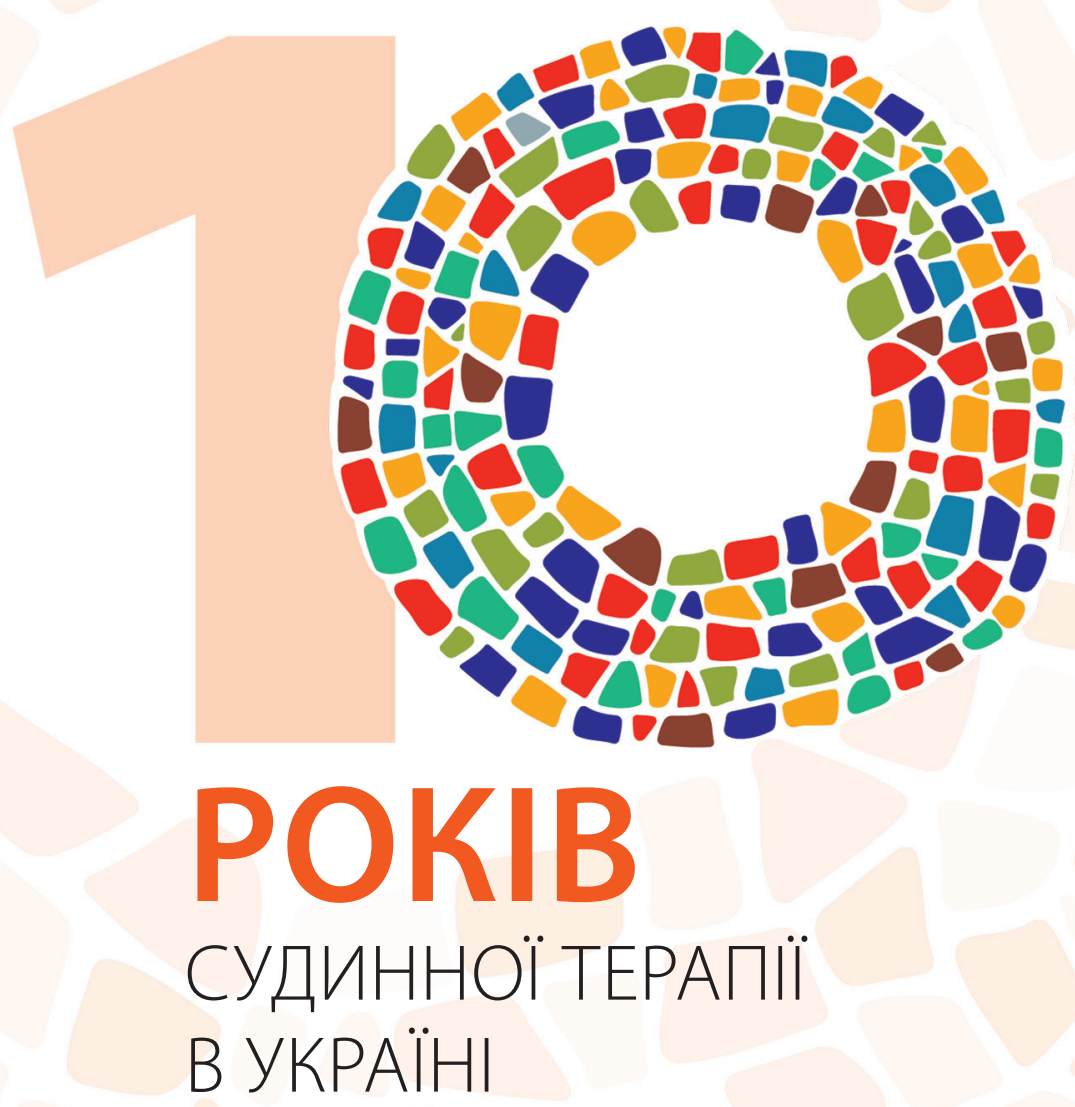

Курс лікування: Тівортін 4 4,2\% розчин 100 мл в/в крапельно 1 раз на добу. Курс - 10 днів. Далі - Тівортін ${ }^{\circledR}$ аспартат розчин для перорального застосування по 1 мірній ложці 3 рази на добу, курс - 14 днів. За необхідності курс лікування повторюють.

Тівортін ${ }^{\circ}$ розчин для інфузій. Лікарська форма: розчин для інфузій у флаконах по 100 мл. Склад: 100 мл розчину містять 4,2 г аргініну гідрохлориду (в 100 мл міститься 20 ммоль аргініну

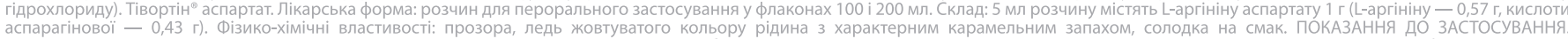
захворювання серцево-судинної системи: у комплексній терапії ішемічної хвороби серця і хронічної серцевої недостатності, атеросклероз судин серця та периферичних судин, мозку стани після, аренесеного гострого порущення мозкового кровообігу захворювання дихальної системи: хронін обструктивні захворювання легень, інтерстиціальна пневмонія, іріолатинн легенева гіпертензія хронічна постемболічна легенева гіпертензія. Захворювання травної системи: гострі та хронічні гепатити різної етіологї̈ печінкова недостатність, печінкова енцефалопатія спричинена гіперамоніємією. ПОБІЧНІ РЕАКЦІї. Рідко - відчуття легкого дискомфорту в шлунку і кишечнику, нудота безпосередньо після застосування препарату, яка зникає самостійно. Головний біль, відчуття жару, флебіт у місці введення розчину. Рідко - алергічні реакції. ПРОТИПОКАЗАННЯ. Гіперчутливість до препарату, гіперхлоремічний ацидоз, діти віком до 18 років. ВЗАЄМОДІЯ 3 ІНШИМИ ЛІКАРСЬКИМИ ПРЕПАРАТАМИ. Поєднане застосування амінофіліну з аргініном може супроводжуватися підвищенням вмісту інсуліну в крові; спіронолактону з аргініном - підвищенням рівня калію в крові. Аргінін несумісний із тіопенталом. СПОСІБ ЗАСТо судинах, гіпоксії, астенічних станах доза препарату може бути збільшена до 200 мл/добу (по 100 мл двічі на добу). Максимальна швидкість введення не має перевищувати 20 ммоль/год. Курс терапіїдіаб днів. Тівортін ложка - 1 г препарату) 3-8 разів на добу. При хронічних обструктивних захворюваннях легень, інтерстиціальній пневмонії, ідіопатичній легеневій гіпертензії, хронічній постемболічній легеневій

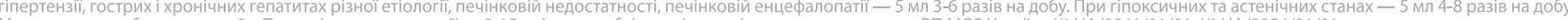
*

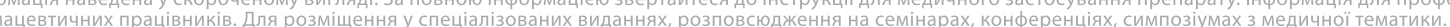

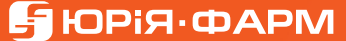

ТОВ «Юрія-Фарм»

03038, м. Київ, вул. М. Амосова, 10.

Тел.: 044-275-01-08 


\section{Обґрунтування необхідності й оцінка ефективності корекції ендотеліальної дисфункції в пацієнтів з анкілозивним спондилоартритом}

Актуальність. За останні роки накопичилося достатньо даних, що свідчать про важливу роль персистуючого запального процесу при запальних захворюваннях суглобів у виникненні серцево-судинних захворювань унаслідок розвитку дисфункції ендотелію, а в подальшому - атеросклерозу, ремоделювання судинної стінки й міокарда. На сьогодні практично не викликає сумнівів: основною причиною того, що рівень несприятливих, загрозливих для життя станів за умов артриту та спондилоартриту значно вищий від загальнопопуляційного, $\epsilon$ серцево-судинні події. Відомо, що одну з провідних ролей у патогенезі ремоделювання судин відіграє дисбаланс між продукцією оксиду азоту, й існує імовірність того, що корекція цієї ланки на ранніх етапах розвитку дозволить запобігти розвитку ендотеліальної дисфункції (ЕД). Мета - визначення поширеності ЕД у пацієнтів із анкілозивним спондилоартритом (AC) та оцінка ефективності комбінованого застосування L-аргініну з метою їі корекції. Об'єкт і методи. У дослідженні взяли участь 110 пацієнтів. Усім учасникам одночасно із протокольним обстеженням проводили оцінку ендотелійзалежної вазодилатації (ЕЗВД) у відповідь на реактивну гіперемію за методом, який уперше описав D.S. Celermajer. 3 метою корекції ЕД застосовували внутрішньовенну інфузію 100 мл 4,2\% розчину донатора оксиду азоту амінокислоти L-аргініну, після чого терапію продовжували прийомом перорального розчинуще протягом 1 міс. Результати. Знижена ЕЗВД(<10\%) відзначена серед хворих на АС у 63, 7\% випадків, причому встановлена вірогідна залежність цього кількісного показника від ступеня запального процесу й дисліпідемій. Після проведеного лікування спостерігали підвищення кількісного значення показника ЕЗВД на 23,2\% $(p<0,05)$, причому його нормалізацію виявлено у $17(42,5 \%)$ пацієнтів (ЕЗВД >10\%), значно покращився стан ендотелію порівняно з вихідним рівнем (8,5\%<ЕЗВД<10,0\%) у 20 (50\%) хворих, і лише у $3(7,5 \%)$ осіб суттєвих змін не констатовано (ЕЗВД <8,5\%) (p<0,05). Висновки. Проведені дослідження дозволяють підтвердити значну поширеність ЕД у пацієнтів із AC. Внутрішньовенне застосування L-аргініну в комплексній терапії пацієнтів із АC упродовж 10 днів із подальшим продовженням прийомуперорального розчинуще протягом 1 міс дозволяє суттєво зменшити вираженість проявів ЕД.

Ключові слова: анкілозивний спондилоартрит, ендотеліальна дисфункція, L-аргінін.

\section{Вступ}

Анкілозивний спондилоартрит (АС) - хронічне системне запальне захворювання з переважним ураженням осьового скелета (крижово-клубових, міжхребцевих, реберно-хребтових зчленувань), що належить до групи серонегативних спондилоартритів (Braun J., Sieper J., 2007; Chen H.A. et al., 2012; Smith J.A., 2015; Brown M.A. et al., 2016; Taurog J.D. et al., 2016). Відомо, що смертність серед пацієнтів із АC у 1,5 раза вища від популяційного рівня (Heeneman S., 2007; Whayne T.F., 2018), вона зумовлена серцево-судинною патологією та хронічною нирковою недостатністю внаслідок амілоїдозу (Heeneman S., 2007; Taurog J.D. et al., 2016; van der Heijde D. et al., 2017).

За останні роки накопичилося достатньо даних, що свідчать про надважливу роль персистуючого запального процесу у виникненні серцево-судинних захворювань (СС3) (Heeneman S., 2007; Ben Assayag E. et al., 2009; Smith J.A., 2015) унаслідок розвитку ендотеліальної дисфункції (ЕД), а в подальшому - атеросклерозу, атеротромбозу, ремоделювання судинної стінки й міокарда (Mehta A. et al., 2018), i, відповідно, це є основною причиною того, що рівень несприятливих, загрозливих для життя станів значно перевищує загальнопопуляційний. 3 огляду на це підвищений рівень С-реактивного білка (СРБ) розглядають як незалежний предиктор розвитку ССЗ та їх ускладнень (Ben Assayag E. et al., 2009; van der Heijde D. et al., 2017). Тривале запалення призводить до активації та пошкодження ендотелію, є причиною атерогенезу (Taurog J.D. et al., 2016; Verma I. et al., 2017) і розвитку гострих серцево-судинних станів, при яких атеросклеротична бляшка дестабілізується і розривається, що призводить до тромбоутворення (Teupser D. et al., 2011). Саме тому запалення набуває особливого значення в розвитку ЕД та серцево-судинної патології в пацієнтів з автоімунними захворюваннями, постійним атрибутом яких $€$ власне персистуюче системне запалення (Syngle A. et al., 2010).

На сьогодні, незважаючи на колосальний інтерес ревматологів до АС та інших спондилоартропатій у світлі сучасного застосування імунобіологічних препаратів для лікування пацієнтів із цими захворюваннями, опубліковано дуже мало робіт щодо розвитку ЕД, впливу запалення на стан ендотелію і розвиток серцевосудинної патології в пацієнтів із АС.

Відповідно до останніх даних, одну з провідних ролей у патогенезі серцево-судинного ремоделювання відіграє дисбаланс між продукцією оксиду азоту (NO) і ангіотензину II, перш за все внаслідок дефіциту NO і надмірних реактивних форм кисню (Altaany Z. et al., 2014; Paulo M. et al., 2014; Donald J.A. et al., 2015).

В ендотеліальних клітинах NO утворюється під дією ферменту ендотеліальної NO-синтетази (eNOS або NOS III) з амінокислоти L-аргініну, що є умовно незамінною амінокислотою та донатором NO (Paulo M. et al., 2014; Zhao Y. et al., 2015).

У низці клінічних досліджень продемонстровано, що при підвищенні активності ендотеліальної NO-синтетази та продукції NO відзначають запобігання розвитку ЕД (Sarojini A. et al., 2013; Paulo M. et al., 2014; Parrinello C.M. et al., 2015).

Мета роботи - визначення поширеності ЕД у пацієнтів із АC та оцінка ефективності комбінованого застосування L-аргініну (Тівортін ${ }^{\oplus}$, Тівортін ${ }^{\oplus}$ аспартат, «Юрія-Фарм», Україна) з метою їі корекції.

\section{Об'єкт і методи дослідження}

У дослідженні взяли участь 110 пацієнтів. Критеріями включення в дослідження були: вірогідний, згідно з модифікованими 
Нью-Йоркськими критеріями (Braun J., Sieper J., 2007), діагноз AC та аксіального й периферичного спондилоартриту (Smith J.A., 2015; van der Heijde D. et al., 2017), інформована згода пацієнта на участь у дослідженні. Критеріями виключення були: вік старше 60 років; наявність псоріазу, хвороби Крона, неспецифічного виразкового коліту, ішемічної хвороби серця, периферичного атеросклерозу, клінічно значущих вад серця (вроджених або набутих), недостатності кровообігу будь-якого генезу, цукрового діабету, тяжкого ураження печінки (активного гепатиту, цирозу), нирок (амілоїдоз чи інша патологія з розвитком хронічної ниркової недостатності), інших хронічних захворювань у фазу загострення (виразка шлунка та дванадцятипалої кишки, холецистит, пієлонефрит тощо).

Усім пацієнтам, які погодилися взяти участь у дослідженні, проводили загальноклінічне стандартне обстеження (загальний аналіз крові, загальний аналіз сечі, електрокардіографію, рентгенографію та магнітно-резонансну томографію крижово-клубових зчленувань), біохімічний аналіз крові з ліпідограмою та визначенням гострофазових показників, виявлення HLA B-27. Клінічну активність недуги визначали за допомогою індексу активност захворювання BASDAI, функціонального індексу BASFI, метрологічного індексу BASMI, якості життя ASQoL (Braun J., Sieper J. 2007; Chen H.A. et al., 2012; van der Heijde D. et al., 2017).

Усім пацієнтам проводили оцінку ендотелійзалежної вазодилатації (ЕЗВД) у відповідь на реактивну гіперемію (потокозалежна вазодилатація) за методом, який уперше описано D.S. Celermajer та співавторами (1992), з використанням ультразвукового комплексу, оснащеного лінійним датчиком. Дослідження проводили в дуплексному режимі (ультразвукове сканування у В-режимі та спектральний аналіз допплерівського сигналу). Виконували проби з реактивною гіперемією (ендотелійзалежний стимул) і нітрогліцерином (ендотелійнезалежний стимул) (Heeneman S., 2007).

ЕЗВД розраховували за формулою:

$$
\text { ЕЗВД }=(d 60-d 0) \cdot 100 \%: d 0,
$$

де $d 60$ - діаметр плечової артерії через 60 с після відновлення кровообігу, $d 0$ - вихідний діаметр плечової артерії.

Ендотелійнезалежну вазодилатацію (ЕНВД) на тлі прийому нітрогліцерину розраховували за формулою:

$$
\text { ЕНВД }=(d 5-d 0) \cdot 100 \%: d 0,
$$

де $d 5$ - діаметр плечової артерії через 5 хв після прийому нітрогліцерину, d0 - вихідний діаметр плечової артерії.

Для оцінки співвідношення між ЕНВД і ЕЗВД розраховували індекс реактивності (IP) плечової артерії за формулою:

$$
\text { IP = ЕНВД/ЕЗВД. }
$$

Після обстеження хворих на АС (110 (100\%)) і виокремлення серед них пацієнтів з ЕЗВД <10\% (70 (63,7\%)) останніх розподілено на дві групи залежно від застосовуваного лікування До 1-ї групи увійшли 30 (27,3\%) хворих, які отримували стандартну терапію аналогічно до групи осіб з ЕЗВД >10\% $(40$ (36,4\%)). Стандартна терапія передбачала застосування лікарських засобів, що зменшують вираженість запалення, зокрема нестероїдних протизапальних засобів у добових дозах: диклофенаку натрію 150 мг/добу або мелоксикаму 15 мг/добу. Пацієнти 2-ї групи $(40(36,4 \%))$ поряд із основним лікуванням протягом 10 днів отримували внутрішньовенно інфузії 100 мл 4,2\% розчину донатора NO амінокислоти L-аргініну (препарат Тівортін ${ }^{\circledR}$ ), після чого терапію продовжували застосуванням перорального розчину ще протягом 1 міс (препарат Тівортін ${ }^{\circledR}$ аспартат). У вихідному стані пацієнти 1-ї та 2-ї груп були репрезентативними за показниками ЕЗВД, статтю, віком, рівнями систолічного та діастолічного артеріального тиску (АТ), частотою серцевих скорочень (ЧСС). Контрольну групу становили практично здорові особи, які були порівнянними за статтю та віком.

Статистичну обробку отриманих результатів проводили методами варіаційної статистики в пакеті прикладних програм SPSS ( ${ }^{\oplus}$ SPSS Inc.) i Statistica ( ${ }^{\oplus}$ Statsoft).

\section{Результати та їх обговорення}

Серед учасників дослідження були 93 (84,5\%) чоловіки (середній вік - 34,5 $\pm 3,4$ року) та $17(15,5 \%)$ жінок (середній вік $38,2 \pm 4,1$ року), тривалість недуги в середньому становила
$12,2 \pm 3,7$ року, причому I ступінь активності констатований у $24(21,8 \%)$, II - у 47 (42,7\%), III - у 39 (35,5\%) хворих відповідно. Результати дослідження функції ендотелію в пацієнтів з АС свідчать, що ЕЗВД плечової артерії у відповідь на реактивну гіперемію хоча й відрізнялася за кількісним значенням від показника у групі контролю, проте несуттєво. Поряд із тим знижену ЕЗВД (<10\%), що $€$ ознакою ЕД, значно частіше виявляли серед хворих на АС порівняно з групою контролю (63,7 та 13,3\% відповідно). ЕНВД значно перевищує ЕЗВД як у пацієнтів з АС, так і в здорових осіб. Однак ЕНВД при АС вірогідно перевищує і ЕНВД у групі контролю (табл. 1).

Таблиця 1. Результати оцінки вазорегулюючої функції ендотелію

\begin{tabular}{lccc}
\hline \multicolumn{1}{c}{ Показник } & $\begin{array}{c}\text { Пацієнти } \\
\text { iз } \mathbf{A C} \\
(\mathbf{n = 1 1 0 )}\end{array}$ & $\begin{array}{c}\text { Контроль } \\
\text { (n=30) }\end{array}$ & p \\
\hline Вихідний діаметр плечової артерії, мм & $4,32 \pm 0,29$ & $3,78 \pm 0,18$ & 0,032 \\
Товщина стінки плечової артерії, мМ & $0,58 \pm 0,06$ & $0,41 \pm 0,03$ & 0,024 \\
Вихідна швидкість кровотоку, м/с & $0,72 \pm 0,09$ & $0,68 \pm 0,07$ & 0,038 \\
ЕЗВД, \% & $8,8 \pm 1,4$ & $12,2 \pm 0,9$ & 0,0012 \\
ЕНВД, \% & $25,8 \pm 1,14$ & $20,7 \pm 3,2$ & 0,0018 \\
ІР плечової артерії & $2,93 \pm 0,12$ & $1,69 \pm 0,14$ & 0,011 \\
\hline
\end{tabular}

p - показник вірогідності порівняно з групою контролю.

Про значуще активну реакцію плечової артерії на екзогенний нітрат при AC свідчить порівняно більше значення IP плечової артерії, що відображає співвідношення ЕНВД і ЕЗВД. Згідно з результатами нещодавно проведених досліджень висловлено припущення, що надмірна реакція плечової артерії на екзогенний нітрат у пацієнтів із АС пов'язана з дефіцитом продукції ендогенного NO й може розцінюватися як ознака ЕД (Kumar A. et al., 2009; Chen H.A. et al., 2012).

Отримані дані демонструють, що в пацієнтів із АС вихідний діаметр плечової артерії та товщина стінки плечової артерії вірогідно більші від аналогічних показників угрупі контролю, а швидкість кровообігу по артерії практично не відрізняється. Це може свідчити про наявність у пацієнтів ознак ремоделювання плечової артерії, активну участь в якому бере ендотелій (Syngle A. et al., 2010; Deyab G. et al., 2017).

Ретельний аналіз залежності ЕД від активності АC і відомих факторів ризику ССЗ показав суттєві взаємообтяжуючі паралелі між рівнями СРБ $(r=0,67)$, холестерину $(r=0,52)$ і ліпопротеїдів низької щільності $(r=0,71)$

Після проведеного лікування отримані дані свідчать, що у 2-й групі спостерігалося значне покращення стану ендотелію. Загалом по групі відзначено зріст кількісного значення показника ЕЗВД на 23,2\% ( $p<0,0023)$, причому його нормалізацію виявлено в $17(42,5 \%)$ пацієнтів (ЕЗВД >10\%). Значне покращення стану ендотелію порівняно з вихідним рівнем $(8,5 \%<$ ЕЗВД<10,0\%) констатовано у 20 (50\%) пацієнтів і лише у 3 (7,5\%) суттєвих змін не спостерігали (ЕЗВД <8,5\%) $(p<0,0023)$. У 1 -й групі на фоні стандартної терапії ЕЗВД змінилася лише на 3,7\% (p>0,05) (рисунок).

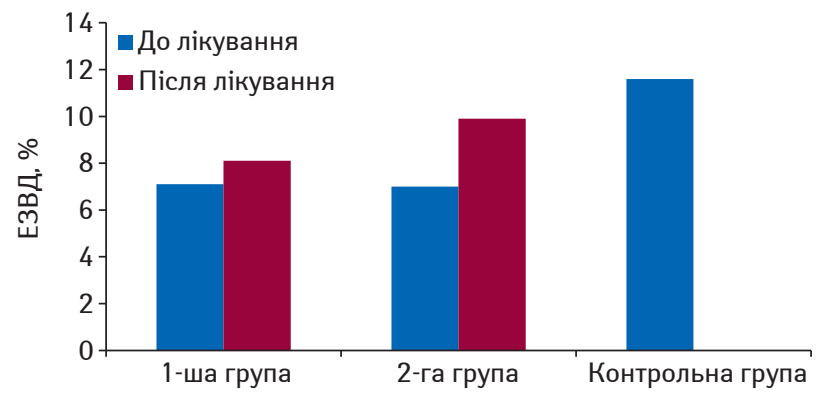

Рисунок. Показники ЕЗВД до і після проведеного лікування

Істотних відмінностей у групах спостереження між впливом стандартної терапії та терапії зі включенням L-аргініну на величину АТ і ЧСС не спостерігали. Значних побічних ефектів при застосуванні препарату не відзначено. Наприкінці дослідження порівняно з початковим станом рівні аланінамінотрансферази, аспартатамінотрансферази, білірубіну та креатиніну не зазнали значних змін на фоні лікування із застосуванням L-аргініну, що свідчить про хорошу переносимість терапії (табл. 2). 
Таблиця 2. Зміни лабораторних та інструментальних показників у хворих на AC при додатковому застосуванні в лікуванні L-аргініну аспартату

\begin{tabular}{|c|c|c|c|c|c|}
\hline \multirow{3}{*}{ Показник } & \multicolumn{5}{|c|}{ Група } \\
\hline & \multicolumn{2}{|c|}{ 1-ша $(n=30)$} & \multicolumn{2}{|c|}{$2-г а(n=40)$} & Контрольна $(\mathrm{n}=20)$ \\
\hline & До лікування & Після лікування & До лікування & Після лікування & Початковий стан \\
\hline ЕЗВД, \% & $8,10 \pm 0,18$ & $8,40 \pm 0,11^{*}$ & $8,20 \pm 0,12$ & $10,1 \pm 1,5^{*}$ & $13,3 \pm 1,1$ \\
\hline САТ, мм рт. ст. & $123,5 \pm 8,8$ & $124,5 \pm 8,5$ & $125,5 \pm 10,3$ & $120,5 \pm 9,0$ & $121,5 \pm 8,3$ \\
\hline ДАТ, мм рт. ст. & $78,5 \pm 4,5$ & $78,7 \pm 4,0$ & $77,5 \pm 5,5$ & $72,5 \pm 3,5$ & $77,5 \pm 3,5$ \\
\hline ЧСС, уд./Хв & $78,5 \pm 5,4$ & $72,4 \pm 2,2$ & $77,4 \pm 2,8$ & $74 \pm 4,2$ & $78,8 \pm 5,6$ \\
\hline Креатинін, мкмоль/л & $62,2 \pm 3,5$ & $63,4 \pm 4,2$ & $63,5 \pm 5,4$ & $64,8 \pm 4,4$ & $58,5 \pm 6,2$ \\
\hline $\begin{array}{l}\text { Загальний холестерин, } \\
\text { ммоль/л }\end{array}$ & $4,92 \pm 0,32$ & $4,9 \pm 0,28^{\#}$ & $4,95 \pm 0,29$ & $4,41 \pm 0,21^{\#}$ & $4,04 \pm 0,22$ \\
\hline $\begin{array}{l}\text { Аланінамінотрансфераза, } \\
\text { Од./л }\end{array}$ & $17,4 \pm 0,7$ & $18,6 \pm 0,8$ & $16,4 \pm 0,9$ & $17,2 \pm 0,7$ & $16,4 \pm 1,2$ \\
\hline $\begin{array}{l}\text { Аспартатамінотрансфераза, } \\
\text { Од./л }\end{array}$ & $18,2 \pm 0,8$ & $19,2 \pm 1,0$ & $17,8 \pm 0,8$ & $19,2 \pm 1,1$ & $18,80 \pm 0,88$ \\
\hline Білірубін, мкмоль/л & $11,2 \pm 1,8$ & $14,4 \pm 2,1$ & $12,3 \pm 1,7$ & $12,8 \pm 1,1$ & $9,4 \pm 1,5$ \\
\hline
\end{tabular}

“Вірогідність відмінностей ЕЗВД між пацієнтами 1-ї та 2-ї груп до та після початку лікування ( $<<0,0023) ;$;вірогідність відмінностей ЕЗВД між пацієнтами 1-ї та 2-ї груп до та після початку лікування ( $p<0,0078)$.

\section{Висновки}

Проведені дослідження дозволяють підтвердити значну поширеність ЕД у пацієнтів з АС, яка, за даними виконаного обстеження, зареєстрована в 63,7\% випадків. Внутрішньовенне застосування L-аргініну у формі 4,2\% розчину в кількості 100 мл у комплексній терапії пацієнтів із АС упродовж 10 днів із подальшим продовженням прийому перорального розчину ще протягом 1 міс дозволяє суттєво зменшити вираженість проявів ЕДшляхом корекції чинників вазоконстрикції та вазодилатації зі значним зростанням ЕЗВД у відповідь на пробу з реактивною гіперемією, а також проявляє деяку гіполіпідемічну дію.

\section{Конфлікт інтересів}

Не заявлений.

\section{Список використаної літератури}

Altaany Z., Moccia F., Munaron L. et al. (2014) Hydrogen sulfide and endothelial dysfunction: relationship with nitric oxide. Curr. Med. Chem., 21(32): 3646-3661.

Ben Assayag E., Shenhar-Tsarfaty S., Bova I. et al. (2009) Association of the $-757 \mathrm{~T}>\mathrm{C}$ polymorphism in the CRP gene with circulating $\mathrm{C}$-reactive protein levels and carotid atherosclerosis. Thromb. Res., 124(4): 458-462.

Braun J., Sieper J. (2007) Ankylosing spondylitis. Lancet, 369: 1379-1390.

Brown M.A., Kenna T., Wordsworth B.P. (2016) Genetics of ankylosing spondylitis-insights into pathogenesis. Nat. Rev. Rheumatol., 12: 81-91.

Celermajer D.S., Sorensen K.E., Gooch V.M. et al. (1992) Noninvasive detection of endothelial dysfunction in children and adults at risk of atherosclerosis Lancet, 340: 1111-1115.

Chen H.A., Chen C.H., Liao H.T. et al. (2012) Clinical, functional, and radiographic differences among juvenileonset, adultonset, and late-onset ankylosing spondylitis. J. Rheumatol., 39(5): 1013-1038.

Deyab G., Hokstad I. , Whist J.E. et al. (2017) Methotrexate and anti-tumor necrosis factor treatment improves endothelial function in patients with inflammatory arthritis. Arthritis Res. Ther., 17, 19(1): 232.

Donald J.A., Forgan L.G., Cameron M.S. (2015) The evolution of nitric oxide signalling in vertebrate blood vessels. J. Comp. Physiol. B., 185(2): 153-171.

Heeneman S. (2007) Cardiovascular risks in spondyloarthritites. Curr. Opin. Rheumatol., 19: 358-362.

Kumar A., Falodia S.K., Shankar S. et al. (2009) Assessment of serum nitrite as biomarker of disease activity in ankylosing spondylitis. Indian J. Rheumatology, 4: 47-50.

Mehta A., Patel J., Al Rifai M. et al. (2018) Inflammation and coronary artery calcification in South Asians: The Mediators of Atherosclerosis in South Asians Living in America (MASALA) study. Atherosclerosis, 29(270): 49-56.

Parrinello C.M., Lutsey P.L., Ballantyne C.M. et al. (2015) Six-yea change in high-sensitivity $\mathrm{C}$-reactive protein and risk of diabetes, cardiovascular disease, and mortality. Am. Heart J., 170(2): 380-389.

Paulo M. , Banin T. M. , de Andrade F.A., Bendhack L. M. (2014) Enhancing vascular relaxing effects of nitric oxide-donor ruthenium complexes. Future Med. Chem., 6(7): 825-838.

Sarojini A., Sai Ravi Shanker A. , Anitha M. (2013) Inflammatory MarkersSerum Level of C-Reactive Protein, Tumor Necrotic Factor- $\alpha$, and Interleukin- 6 as Predictors of Outcome for Peripartum Cardiomyopathy. J. Obstet. Gynaecol. India, 63(4): 234-239.

Smith J.A. (2015) Update on ankylosing spondylitis: current concepts in pathogenesis. Curr. Allergy Asthma Rep., 15(1): 489

Syngle A., Vohra K., Sharma A., Kaur L. (2010) Endothelial dysfunction in ankylosing spondylitis improves after tumor necrosis factor-a blockade. Clin. Rheumatol., 29: 763-770.
Taurog J.D., Chhabbra A., Colbert R.A. (2016) Axial spondyloarthritis and ankylosing spondylitis. New Engl. J. Med., 26: 2563-2574.

Teupser D., Weber O., Rao T.N. et al. (2011) No reduction of atherosclerosis in C-reactive protein (CRP)-deficient mice. J. Biol. Chem., 286(8): 6272-6279.

van der Heijde D., Ramiro S., Landewé R. et al. (2017) 2016 update of the ASAS-EULAR management recommendations for axial spondyloarthritis. Ann. Rheum. Dis., 76(6): 978-991.

Verma I., Syngle A., Krishan P., Garg N. (2017) Endothelial Progenitor Cells as a Marker of Endothelial Dysfunction and Atherosclerosis in Ankylosing Spondylitis: A Cross-Sectional Study. Int. J. Angiol., 26(1): 36-42.

Whayne T.F. (2018) Non-traditional Cardiovascular Risk Markers in the Era of Established Major Risk Factors and Multiple Guidelines. Curr. Vasc. Pharmacol., Jan. 22 [Epub. ahead of print]

Zhao Y., Vanhoutte P.M. , Leung S.W. (2015) Vascular nitric oxide: Beyond eNOS. J. Pharmacol. Sci., 129(2): 83-94.

\section{Обоснование необходимости}

\section{и оценка эффективности коррекции эндотелиальной дисфункции у пациентов с анкилозирующим спондилоартритом}

\section{С.И. Смеян, Б.О. Кошак}

Резюме. Актуальность. В последние годы накопилось достаточно данных, свидетельствующих о важной роли персистирующего воспалительного процесса при воспалительных заболеваниях суставов в возникновении сердечно-сосудистых заболеваний вследствие развития дисфункции эндотелия, а в дальнейшем - атеросклероза, ремоделирования сосудистой стенки и миокарда. Сегодня практически не вызывает сомнений: основной причиной того, что уровень неблагоприятных, угрожающих жизни состояний в условиях артритов и спондилоартритов значительного превышает общепопуляционный, являются сердечно-сосудистые события. Известно, что одну из ведущих ролей в патогенезе ремоделирования сосудов играет дисбаланс между продукцией NO, и существует вероятность того, что коррекция данного звена на ранних этапах развития позволит предотвратить развитие эндотелиальной дисфункции (ЭД). Цель - определение распространенности ЭД у пациентов с анкилозирующим спондилоартритом (AC) и оценка эффективности комбинированного применения L-аргинина с целью ее коррекции. Объект и методы. В исследовании приняли участие 110 пациентов. Всем участникам наряду с протокольным обследованием проводили оценку эндотелийзависимой вазодилатации (ЭЗВД) в ответ на реактивную гиперемию по методу, который впервые описал D.S. Celermajer. С целью коррекции ЭД применяли внутривенную инфузию 100 мл 4,2\% раствора донатора оксида азота аминокислоты L-аргинина, после чего терапию продолжали приемом раствора еще в течение 1 мес. $\underline{P e-}$ зультаты. Сниженная ЭЗВД (<10\%) отмечена среди больных АС в 63,7\% случаев, причем установлена достоверная зависимость этого количественного показателя от степени воспалительного процесса и дислипидемий. После проведенного лечения отмечено повышение количественного значения показателя ЭЗВД на 23,2\% ( $p<0,05)$, причем его нормализация выявлена у 17(42,5\%) пациентов (ЭЗВД > 10\%), значительно улучшилось состояние эндотелия по сравнению с исходным уровнем (8,5\%<Э3ВД<10,0\%) у 20 (50\%) больных, и только у $3(7,5 \%)$ человек существенные изменения не констатированы(ЭЗВД<8,5\%) (p<0,05). Выводы. Проведенные исследования позволяют подтвердить значительную распространенность ЭД упациентов с AC. Внутривенное применение L-аргинина в комплексной терапии больных $A C$ в течение 10 дней с последующим продол- 
жением приема перорального раствора еще в течение 1 мес позволяет существенно уменьшить выраженность проявлений ЭД.

Ключевые слова: анкилозирующий спондилоартрит, эндотелиальная дисфункция, L-аргинин.

\section{Substantiation of necessity and evaluation of endothelial dysfunction correction efficiency in patients with ankylosing spondylitis}

\section{S.I. Smiian, B.O. Koshak}

Summary. Background. In recent years, sufficient data has been accumulated about the important role of the persistent inflammatory process in inflammatory diseases of the joints in the occurrence of cardiovascular diseases due to the development of endothelial dysfunction, and in the future - atherosclerosis, remodeling of the vascular wall and myocardium. Today, there is little doubt: cardiovascular events are the main cause of the fact that the level of adverse, life-threatening conditions in arthritis and spondylarthritis is much higher than that of general population. It is known that imbalance of nitric oxide production plays one of the leading roles in the pathogenesis of vascular remodeling, and there is a possibility that correction of this link in the early stages of development will prevent endothelial dysfunction (ED). Objective - to determine the prevalence of
ED in patients with ankylosing spondylitis (AS) and to evaluate the effectiveness of the combined use of L-arginine for its correction. Materials and methods. The study included 110 patients. In all of them, along with the protocol examination, endothelium-dependent vasodilation (EDVD) in response to reactive hyperemia was evaluated according to the method first described by D.S. Celermajer. In order to correct ED, we have used $100 \mathrm{ml}$ of $4.2 \%$ solution of a nitric oxide donor, L-arginine amino acid, as intravenous infusions followed by continued oral therapy for 1 month. Results. Reduced EDVD (<10\%) was detected among patients with AS in $63.7 \%$ of cases, and the probable dependence of this quantitative index on the degree of inflammation and dyslipidemia was established. After the treatment, an increase was noted in the quantitative value of the EDVD indicator by $23.2 \%(p<0.05)$, with its normalization in $17(42.5 \%)$ patients (EDVD $>10 \%$ ), endothelium state improved significantly compared to the baseline level $(8.5 \%<E D V D<10.0 \%)$ in $20(50 \%)$ patients, and only $3(7.5 \%)$ patients did not report any significant changes $(E D V D<8.5 \%)(p<0.05)$. Conclusions. The performed studies can confirm the significant prevalence of ED in patients with AS. The use of $L$-arginine in the comprehensive treatment of AS patients for 10 days with subsequent continuation of oral administration for another 1 month can significantly reduce the manifestations of $E D$.

Key words: ankylosing spondylitis, endothelial dysfunction, L-arginine.

Одержано 26.06.2018

\section{РЕФЕРАТИВНА ІНФОРМАЦІЯ}

\section{Установлены причины развития возрастной периферической нейропатии}

\section{Актуальность}

В настоящее время в мире отмечается возрастание средней продолжительности жизни. Наряду с этим подобная тенденция сопряжена с увеличением числа возрастных заболеваний нервной системы, таких как болезнь Альцгеймера и другие формы деменций.

Биологическое старение рассматривается как один из основных факторов, обусловливающих развитие структурных и функциональных изменений нервной системы, в частности развития периферической нейропатии. При этом закономерно, что патологические нарушения затрагивают не только структуры центральной нервной системы. Периферическая нервная система, отвечающая, например, за иннервацию мышц и кожи, также подвержена дегенеративным изменениям в связи с биологическим старением организма.

Несмотря на то что последствия возрастной дегенерации периферических нервов оказывают значимое влияние на качество жизни людей преклонного возраста, возможные триггеры этого процесса все еще недостаточно изучены.

В недавнем исследовательском проекте, осуществленном учеными неврологического отделения Вюрцбургской университетской клиники (Neurological Department of the Würzburg University Hospital), Германия, описаны важные аспекты возрастной дегенерации периферических нервных структур. По мнению авторов, новые данные впоследствии могут быть рассмотрены в качестве мишени терапии указанных состояний.

\section{Материалы и результаты исследования}

Работая совместно с научными сотрудниками Университета Аахена (University of Aachen), Германия, на начальном этапе исследования ученые провели систематический анализ морфофункциональных изменений, наблюдаемых в периферических нервах лиц в возрасте 65-79 лет. В изучаемых образцах установлено возрастание числа макрофагов. Основываясь на представлении о том, что макрофаги, выполняя в организме функции преобразования и элиминации чужеродных структур, клеточного детрита, стареющих клеток, могут по тому же принципу инициировать и патогенез тех или иных процессов, исследователи поставили перед собой задачу выяснить, относится ли это предположение также и к развитию возрастной дегенерации нервов.

С этой целью проведено экспериментальное исследование лабораторных животных. Изучены образцы периферических нервов мышей в возрасте 24 мес. Оказалось, что наблюдаемые из- менения у животных схожи с таковыми у людей. В частности, число макрофагов у старших особей увеличено наряду со уменьшением у них мышечной силы, а также изменениями в моторных терминалях - синапсах, соединяющих нервы и мышечные волокна.

На последующем этапе работы командой исследователей изучен вопрос о том, действительно ли макрофаги отвечают за запуск этих изменений. С этой целью внесены изменения в рацион питания мышей в возрасте 18 мес. Ежедневно животные получали ингибитор специфической киназы CSF-1R. Результатом этого стало уменьшение количества макрофагов на $70 \%$ от исходных показателей при отсутствии регистрируемых побочных эффектов. После 6 мес подобной коррекционной терапии ученые констатировали, что процессы возрастной дегенерации периферических нервных структур у животных основной группы значимо менее выражены. Соответственно, показатели мышечной силы и состояние терминальных синаптических структур улучшались по сравнению с аналогичными особенностями животных контрольной группы.

\section{Выводы и перспективы исследований}

Таким образом, в проведенной работе ученым удалось продемонстрировать не только причинно-следственную связь между воспалительными реакциями в стареющих нервных тканях и процессами дегенеративного старения, но также и то, что это состояние поддается направленной коррекции. По их мнению, целенаправленное лечение возрастных состояний, обусловленных спецификой функций макрофагов, может оказать позитивный эффект на морфофункциональное состояние нервных структур, а вместе с этим улучшить мобильность и качество жизни в преклонном возрасте.

Кроме того, авторы предположили, что интерпретация полученных результатов также позволяет сформулировать более расширенные выводы. Поскольку инфекционные и хронические возрастные заболевания, например сахарный диабет, часто сопряжены с воспалительными реакциями, такие состояния, вероятно, представляют собой дополнительный риск для периферических нервов. Поэтому ученые надеются, что полученные результаты будут способствовать запуску будущих исследований и разработке препаратов, селективно влияющих на макрофаги.

University of Würzburg (2018) When muscles weaken with age. ScienceDaily, Jun. 19.

Yuan X., Klein D., Kerscher S. et al. (2018) Macrophage depletion ameliorates peripheral neuropathy in aging mice. J. Neurosci., 38 (19): 4610-4620.

Наталья Савельева-Кулик 